\title{
A rare disc-like holdfast of the Ediacaran macroalga from South China
}

\author{
Ye Wang, ${ }^{1}$ Yue Wang, ${ }^{2, *}$ and Wei $\mathrm{Du}^{3}$ \\ ${ }^{1}$ School of Earth Sciences and Resources, China University of Geosciences, Beijing 100083, China 〈gboywangye@126.com〉 \\ ${ }^{2}$ School of Resources and Environments, Guizhou University, Guiyang 550025, China 〈gzyuewang@126.com〉 \\ ${ }^{3}$ Department of Earth Science and Astronomy, The University of Tokyo, Tokyo 153-8902, Japan 〈duwei@ea.c.u-tokyo.ac.jp〉
}

\begin{abstract}
The fixing organ of the Precambrian macroalga was briefly described by most researchers as a holdfast or rhizoid, suggesting a fixation structure and/or tissue differentiation. An Ediacaran macroscopic alga, Discusphyton whenghuiensis n. gen. n. sp., with a complex disc-like holdfast and an unbranching thallus, has been collected, together with abundant and diverse macrofossils (i.e., the Wenghui biota) in black shales of the upper Doushantuo Formation ( $\sim 560-551 \mathrm{Ma})$ in northeastern Guizhou, South China. The Wenghui biota lived in a relatively low-energy marine environment and was preserved in situ or nearby their growth position. Morphologically, the macroalgal thallus, including the compressed lamina and cylindrical stipe, might have been suspended in the water column for photosynthesis. Its holdfast, a rare fixing form, is complex in structure and construction, consisting of a globular rhizome and a discoidal rhizoid. The large-sized discoidal rhizoid is regarded as a flat-bottomed and domeshaped organ to attach the macroalga on the water-rich muddy seafloor. The globular rhizome, expanded by a thallus on the substrate, was originally harder and spherical nature within the dome-shaped rhizoid. It may have been an important organ as a steering knuckle to connect between the stipe and the rhizoid. The macroscopic metaphyte D. whenghuiensis $\mathrm{n}$. gen. $\mathrm{n}$. sp. shows the appearance of complex holdfast in morphology and bio-functions. However, not enough is known, in the absence of more information, to decipher the phylogenetic affinity of D. whenghuiensis $\mathrm{n}$. gen. $\mathrm{n}$. sp. and the origin of a discoidal rhizoid.
\end{abstract}

\section{Introduction}

Abundant and diverse carbonaceous compressions (the Wenghui biota), including macroscopic macroalgae, metazoans, and ichnofossils, are found in the Ediacaran black shales of the upper Doushantuo Formation in northeast Guizhou, South China (Wang et al., 2005, 2007, 2008, 2009, 2010, 2011, 2012, 2014, 2015a, 2016a; Tang et al., 2008a, 2008b, 2009; Wang and Wang, 2008, 2011; Zhu et al., 2008). A disc-like compression, with an unbranching carbonaceous stipe growing out from its center, is one of the abundant taxa in the Wenghui biota. Nevertheless, the Ediacaran disc-like compression, including system description and name, has remained poorly understood in terms of classification and functional morphology. Wang et al. (2005) first reported a single image of the disc-like compression, and regarded it as a holdfast of macroscopic alga, enabling its owner to live on water-rich clay sediments. Wang and Wang (2006) and Wang et al. (2007) considered the unbranching thallus with a disc-like holdfast as a significant embodiment of organic differentiations of macroalga. Wang et al. (2007) combined and described the various holdfasts preserved together with the algal thallus as "unnamed holdfast forms" of macroalgae, including discoidal, spherical, asteroidal, cone-shaped, and filamentous holdfasts. Many researchers also interpreted the disc-like compression as a

\footnotetext{
* Corresponding author: Yue Wang 〈gzyuewang@126.com〉
}

holdfast of macroscopic alga (Tang et al., 2008, 2009; Wang et al., 2010, 2014, 2015b; Cheng et al., 2013). In addition, a half-circle holdfast with an unbranching thallus was assigned by Tang et al. (2008a, 2014) and Wang et al. (2009) to the macroalga Gesinella Steiner et al., 1992 and Baculiphyca Yuan et al., 1995, respectively.

More recently, numerous specimens of the disc-like compression have been collected in black shales of the upper Doushantuo Formation at Wenghui Village, Jiangkou County, Guizhou Province, South China (Fig. 1). These well-preserved compressions provide new information on its affinity and biological function.

\section{Stratigraphical and environmental settings}

In the Wenghui section $\left(27^{\circ} 50^{\prime} 07^{\prime \prime} \mathrm{N}, 109^{\circ} 01^{\prime} 20^{\prime \prime} \mathrm{E}\right)$, the Ediacaran Doushantuo Formation ( $>71 \mathrm{~m}$ thick) is divided into four members. The lowest Member I is composed of dolostones (cap carbonates), overlying tillites of the Nantuo Formation. The overlying Member II consists of black shales and dolostones. Member III is characterized by dolostones and muddy dolostones, with black shales. The uppermost Member IV consists of fossiliferous black shales, underlying bedded cherts of the Liuchapo Formation (Fig. 1). Apart from the disc-like compression, abundant and diverse macroscopic fossils (i.e., the Wenghui biota) have been collected in black shales of the Member IV 

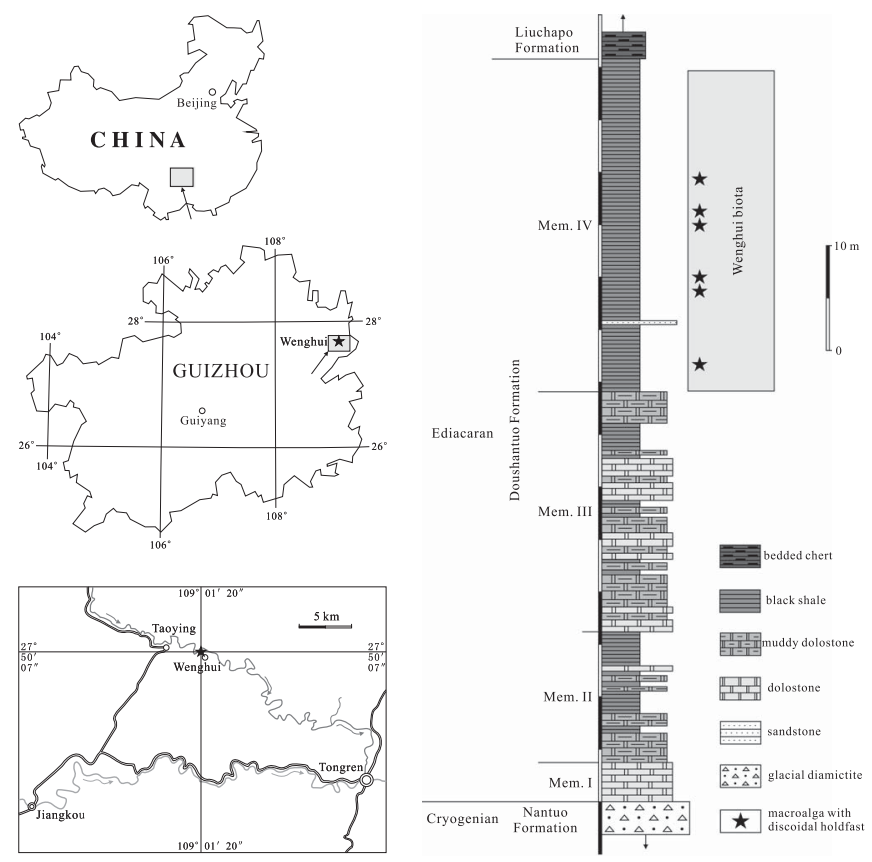

Figure 1. Ediacaran Doushantuo Formation stratigaphic section at Wenghui, Jiangkou, northeastern Guizhou, South China. Disc-like compressions with carbonaceous stipes described in this paper are found in upper Doushantuo black shales at Wenghui.

(e.g., Wang et al., 2005, 2007, 2008, 2009, 2010, 2011, 2014, 2015a, 2016a; Wang and Wang, 2006, 2008, 2011; Tang et al., 2008a, 2008b, 2009; Zhu et al., 2008; Cheng et al., 2013).

Another Ediacaran marcrobiota, the Miaohe biota, was also found in black shales of the Doushantuo Member IV at Miaohe, Yangtze Gorges area, South China (see Zhu and Chen, 1984; Chen and Xiao, 1991, 1992; Chen et al., 1994a, 2000; Ding et al., 1996; Xiao et al., 2002, 2013; Yuan et al., 2002). Both the Miaohe and Wenghui biotas can be paleontologically correlated (e.g., Baculiphyca taeniata Yuan, Li, and Chen, 1995, emend. Xiao et al., 2002; Beltanelliformis brunsae Menner in Keller et al., 1974; Enteromorphites siniansis Zhu and Chen, 1984, emend. Wang, Wang, and Huang, 2007; Eoandromeda octobrachiata Tang et al., 2008b; Liulingjitaenia alloplecta Chen and Xiao,1992, emend. Xiao et al., 2002; Longifuniculum dissolutum Steiner, Erdtmann, and Chen, 1992; Miaohephyton bifurcatum Steiner, 1994, emend. Xiao, Knoll, and Yuan, 1998; Protoconites minor Chen, Xiao, and Yuan, 1994a, emend. Wang, Wang, and Huang, 2007; and Zhongbaodaophyton crassa Chen, Xiao, and Yuan, 1994a, emend. Wang, Wang, and Huang, 2007). Lithologically, the Doushantuo successions can be correlated in both the Miaohe and Wenghui sections (Qin et al., 1984; Wang et al., 1987; Liu and Xu, 1994; Zhu et al., 2007; Jiang et al., 2011; Wang et al., 2012). In the Yangtze Gorges area, a zircon U-Pb thermal ionization mass spectrometry age from the top of the Doushantuo Formation is $551.1 \pm 0.7 \mathrm{Ma}$ (Condon et al., 2005) and a Re-Os age of the base black shale of the Doushantuo Member IV is $591 \pm 5.3 \mathrm{Ma}$ (Zhu et al., 2013). However, Kendall et al. (2015) suggested that the $591 \pm 5.3 \mathrm{Ma}$ Re-Os age may reflect post-depositional alteration and estimated the age of Member IV, pointing to extensively oxygenated oceans, as $\sim 560-551 \mathrm{Myr}$.
In the Wenghui biota, not only macroscopic fossils but also filamentous rhizoids of macroalgae are well preserved, therefore previous researchers generally considered that this biota lived in a relatively low-energy environment and was preserved in situ or nearby their growth position (Wang et al., 2005, 2007, 2009, 2011, 2014, 2015a, 2016a; Wang and Wang, 2006, 2011; Cheng et al., 2013).

\section{Materials and methods}

Repository and institutional abbreviation.-All studied specimens from Member IV of the Ediacaran Doushantuo Formation in the Wenghui section are preserved as carbonized compressions. These specimens are reposited in Guizhou University, China.

\section{Systematic paleontology}

\section{Genus Discusphyton new genus}

Type species.—Discusphyton wenghuiensis $\mathrm{n}$. gen. n. sp.

Etymology.-From the Latin discus and phyton, with reference to the dis-like holdfast with an unbranching thallus.

Diagnosis.-Unbranching clavate thallus stalked on the center of a disc-like or half-circle holdfast. Stipe (lower part of thallus) is cylindrical, upper part compressed to a lamina. The thallus substrate expands to a globular structure (globular rhizome), embedded into the smooth discoidal rhizoid. The disc-like holdfast comprises a globular rhizome and a discoidal rhizoid (Fig. 2).

Discussion.-The fixing organ of the Precambrian macroalga was briefly described by most researchers as holdfast or rhizoid (e.g., Du, 1982; Chen and Xiao, 1991, 1992; Steiner et al., 1992; Steiner, 1994; Chen et al., 1994a, 2000; Zhu and Chen, 1995; Yuan et al., 1995, 1999, 2002, 2011; Ding et al., 1996; Chen and Wang, 2002; Xiao et al., 2002; Wang et al., 2007, 2016a; Tang et al., 2008a, 2009; Singh et al., 2009). The Ediacaran macroalgal holdfast was divided by Wang and Wang (2006b) into stem-holdfast (upper part of the expanded thallus substrate), pedicel-holdfast (lower part of the expanded thallus substrate), and filament-rhizoid (grow on the expanded thallus substrate). Wang et al. (2015b) considered that the holdfast of the Ediacaran macroalga Zhongbaodaophyton consists of the tuberous rhizome expanded thallus substrate and the filamentous rhizoids growing on the rhizome. The disc-like holdfast of Discusphyton n. gen. obviously consisted of a globular rhizome and a discoidal rhizoid.

The compression is characterized by an unbranching thallus stalked on the center of a smooth disc-like holdfast, without filamentous rhizoids, which differs from other Ediacaran macroscopic algae. It also differs from the Pre-Ediacaran macroalgae with disco-like holdfast in its large-sized discoidal rhizoid.

In the Ediacaran period, many discoidal metazoans were reported in many areas of the world (e.g., Sprigg, 1947; Wade, 


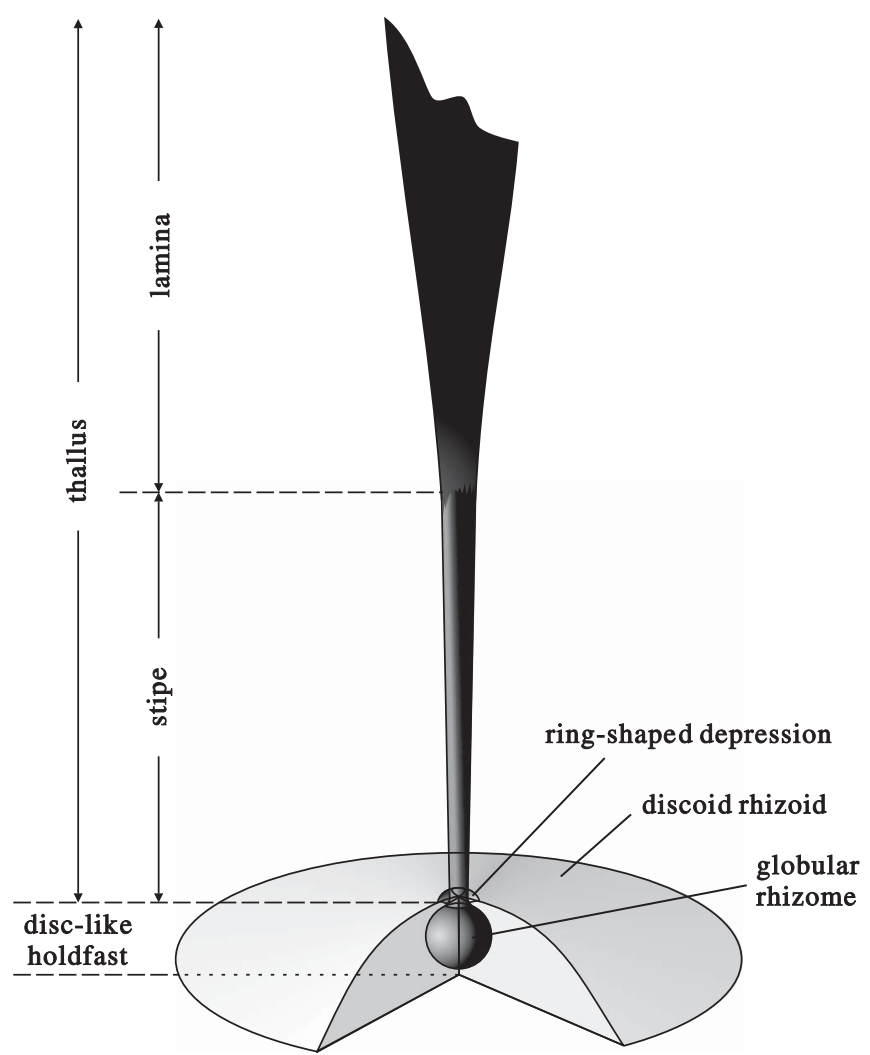

Figure 2. Drawing of the principal structures of Discusphyton wenghuiensis n. gen. n. sp.

1972; Duan and Lin, 1980; Fedonkin, 1982; Glaessner, 1984; Sun, 1986; Seilacher, 1992, 1999; Farmer et al., 1992; De, 2003; McCall, 2006; Zhang et al., 2006; Serezhnikova, 2007; Tang et al., 2008b; Wang et al., 2008, 2011, 2012a, 2016a). Tang et al. (2014) considered that the macroalgal holdfasts, that had fallen off the thallus and been preserved independently, were similar to or possibly mistaken as the disc-like metazoan. Discusphyton n. gen. differs from these Ediacaran metazoans in its discoid-like compression with smooth face and unbranching thallus, without concentric or radiating structure.

\section{Discusphyton wenghuiensis new genus new species} Figures 2, 3.1-3.11, 4.1-4.9

2005 Macroalgal holdfast [gen. et sp. indet.] Wang et al., fig. 4.10.

2006 Macroalgal holdfast [gen. et sp. indet.] Wang et al., pl. 2, fig. j.

2007 Unnamed holdfast forms [gen. et sp. indet.] Wang et al., p. 836, pl. 2, fig. 23.

2008a Macroalgal holdfast [gen. et sp. indet.] Tang et al., pl. 1, fig. 12.

2008a Gesinella hunanensis Steiner et al., 1992; Tang et al., pl. 2, fig. 19.

2009 Baculiphyca sp. Wang et al., fig. 2.2.

2009 Macrooscopic alga fossil [gen. et sp. indet.] Tang et al., fig. $2 \mathrm{~g}$.

2013 Discoidal rhizoid of macroalga [gen. et sp. indet.] Cheng et al., fig. 1.3.
2014 Macroalgal holdfast [gen. et sp. indet.] Wang et al., fig. $4 \mathrm{p}$.

2014 Gesinella [sp. indet.] Steiner et al., 1992; Tang et al., fig. 2.2.

2014 Discoidal holdfast [gen. et sp. indet.] Wang et al., figs. 5A, B.

Etymology.-After the village of Wenghui in Jiangkou County, northeastern Guizhou Province, South China, in where abundant macroscopic fossils are collected.

Material.-57 specimens from the Wenghui section in northeastern Guizhou, South China.

Types.-Holotype, WH50-1460 (Fig. 3.1); Paratypes, WH-P-5014 (Fig. 3.2) and JK48-0031 (Fig. 4.1, 4.2).

Diagnosis.—As for genus.

Description.-Carbonaceous compression having a disc-like holdfast and an unbranching algal thallus (Fig. 3). The disc-like holdfast consists of a discoidal rhizoid and a globular rhizome. The discoidal rhizoid, with smooth surface and edge, typically is preserved in the bedding planes as a circular carbonaceous film or mass that commonly has nonuniform density, gradually lighting in color from the center to the edge (Figs. 3.1-3.3, 3.5, $3.11,4.1,4.3,4.5-4.9$ ). In a small number of specimens, it is preserved as a half-circle (Fig. 3.6-3.10) in which two arc-shaped edges are observed (Figs. 3.7, 4.8), which appear to be folded discoidal rhizoids. The globular rhizome, a globular structure within the discoidal rhizoid, is expanded by the thallus substrate and bears a smooth surface (Fig. 3.1, 3.2, 3.6). The carbonaceous density of the globular rhizome is thicker than that of the discoidal rhizoid, forming an obvious border between them (Fig. 3.1, 3.2, 3.6, 3.11). On the surface of the discoidal rhizoid center, it generally has a more or less rounded hump (Figs. 3.3-3.5, 3.7-3.11, 4.2, 4.6-4.8), possibly formed by the globular rhizome. The unbranching clavate thallus is incompletely preserved. The lower part of thallus, a terete stipe, is three-dimensionally preserved (Fig. 3.1-3.5, 3.7-3.10), with smallest diameter at the primal stipe (connection between stipe and rhizome) and increasing gradually upwards in diameter (Fig. 3). Connecting with the stipe, the compressed lamina (upper part of thallus) is a rapidly expanded portion (Fig. 3.6, $3.7,3.9$ ), but not observed the completely preserved lamina. In some specimens that thallus has fallen off, a circular cross section of the stipe remains on the center of the discoidal rhizoid (Fig. 4). A shallow, ring-shaped depression surrounding the primal stipe is present on the surface of the discoidal rhizoid (Fig. 4.1, 4.2, 4.5-4.9). The discoidal rhizoid is $3.0-14.9 \mathrm{~mm}$ in diameter. The longest preserved thallus is $14.6 \mathrm{~mm}$. The globular rhizome is $0.6-2.9 \mathrm{~mm}$ in diameter. The stipe is $3.4-$ $9.7 \mathrm{~mm}$ in length and $1.7 \mathrm{~mm}$ in the preserved maximum diameter. The lamina is $17.4 \mathrm{~mm}$ and $4.1 \mathrm{~mm}$ in the preserved maximum length and maximum width, respectively. The growth rates of the stipe width and the lamina width per unit length ( $=$ [difference between maximum and minimum widths]/ [length between two measuring points] $\times 100 \%$ ) are $0.9-9.2 \%$ and $12.9-25.4 \%$, respectively. 

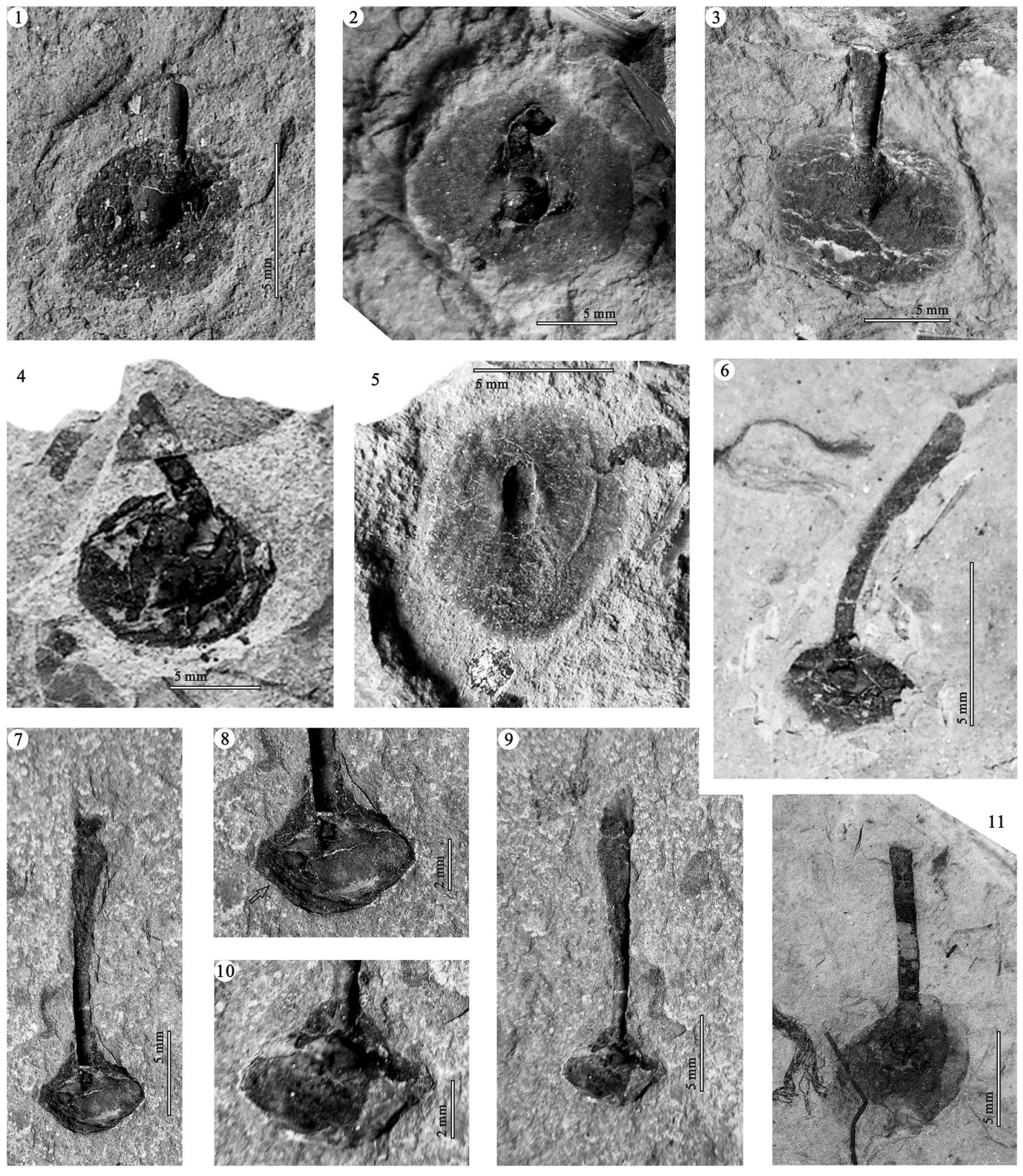

Figure 3. Discusphyton wenghuiensis n. gen. n. sp. from the upper Doushantuo Formation, Wenghui, Jiangkou, Guizhou, China. (1) Holotype JK50-1460; (2) paratype WH-P-50014; (3) WH-P-42146; (4) JK45-0717; (5) TY42-147; (6) JK42-1064; (7, 8) JK42-0146, with magnified view of the holdfast; arrow marks detail of folds; (9, 10) JK42-0147, with magnified view of the holdfast; (11) WH-P-04120.

Discussion.-Discusphyton wenghuiensis n. gen. n. sp. is similar to Gesinella hunanensis (Steiner et al., 1992) in the unbranching thallus, but the later has a cone-shaped rhizome with many filamentous rhizoids (see Steiner et al., 1992; Steiner,
1994; Chen and Wang, 2002; Wang et al., 2007, 2009, 2014; Tang et al., 2008a). Similarly, D. wenghuiensis n. gen. n. sp. is different from the other unbranching macroalga Baculiphyca taeniata Yuan et al., 1995, emend. Xiao et al., 2002 by its disc-like 

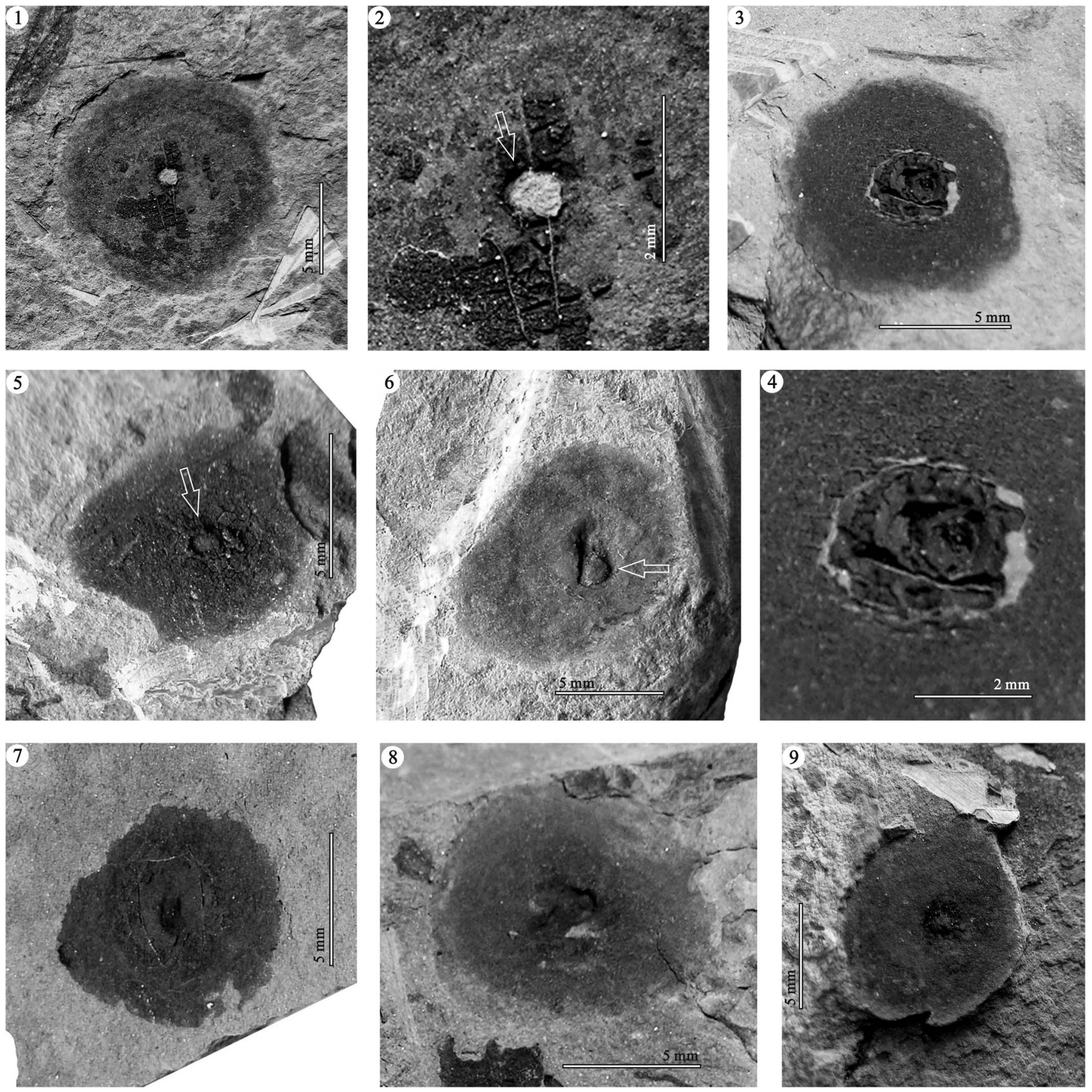

Figure 4. Discusphyton wenghuiensis n. gen. n. sp. fallen from thallus from the upper Doushantuo Formation, Wenghui, Jiangkou, Guizhou, China. $(\mathbf{1 , 2})$ Paratype JK48-0031, with magnified view of the central part; $(\mathbf{3}, \mathbf{4})$ WH-P-01060, with magnified view of the central part; (5) TY42-0014; $(\mathbf{6})$ TY50-0082; (7) WH-P-01087; (8) WH-P-01051; (9) WH-P-01022. Arrows in 2, 5, and 6 mark the ring-shaped depression.

holdfast without filamentous rhizoid. With a disc-like holdfast, Sitaulia minor Singh, Babu, and Shukla, 2009 from the Sirbu Shale Formation in India consist of an oval-shaped thallus and an indistinct disc-like holdfast (see Singh et al., 2009, p. 14, pl. 1i) that differs from $D$. whenghuiensis $\mathrm{n}$. gen. $\mathrm{n}$. sp. In addition, the identifiable disc-like holdfast of $D$. wenghuiensis $\mathrm{n}$. gen. n. sp. in this paper is $>3.0 \mathrm{~mm}$ in diameter. In summary, the small-sized holdfast of D. wenghuiensis $\mathrm{n}$. gen. $\mathrm{n}$. sp. is similar to other smallsized circular macroalgae (e.g., Chuaria Walcott, 1899 and Beltanelliformia Menner in Keller et al., 1974), but the disc-like holdfast of D. wenghuiensis n. gen. n. sp. bears a smooth surface and a circular cross section of the stipe on its center.

Occurrence.-Upper Doushantuo black shales of the Ediacaran at Wenghui, Jiangkou, Guizhou, China.

\section{Measurements}

The morphometric parameters of Discusphyton wenghuiensis n. gen. n. sp., including the diameters of both the discoidal rhizoid 

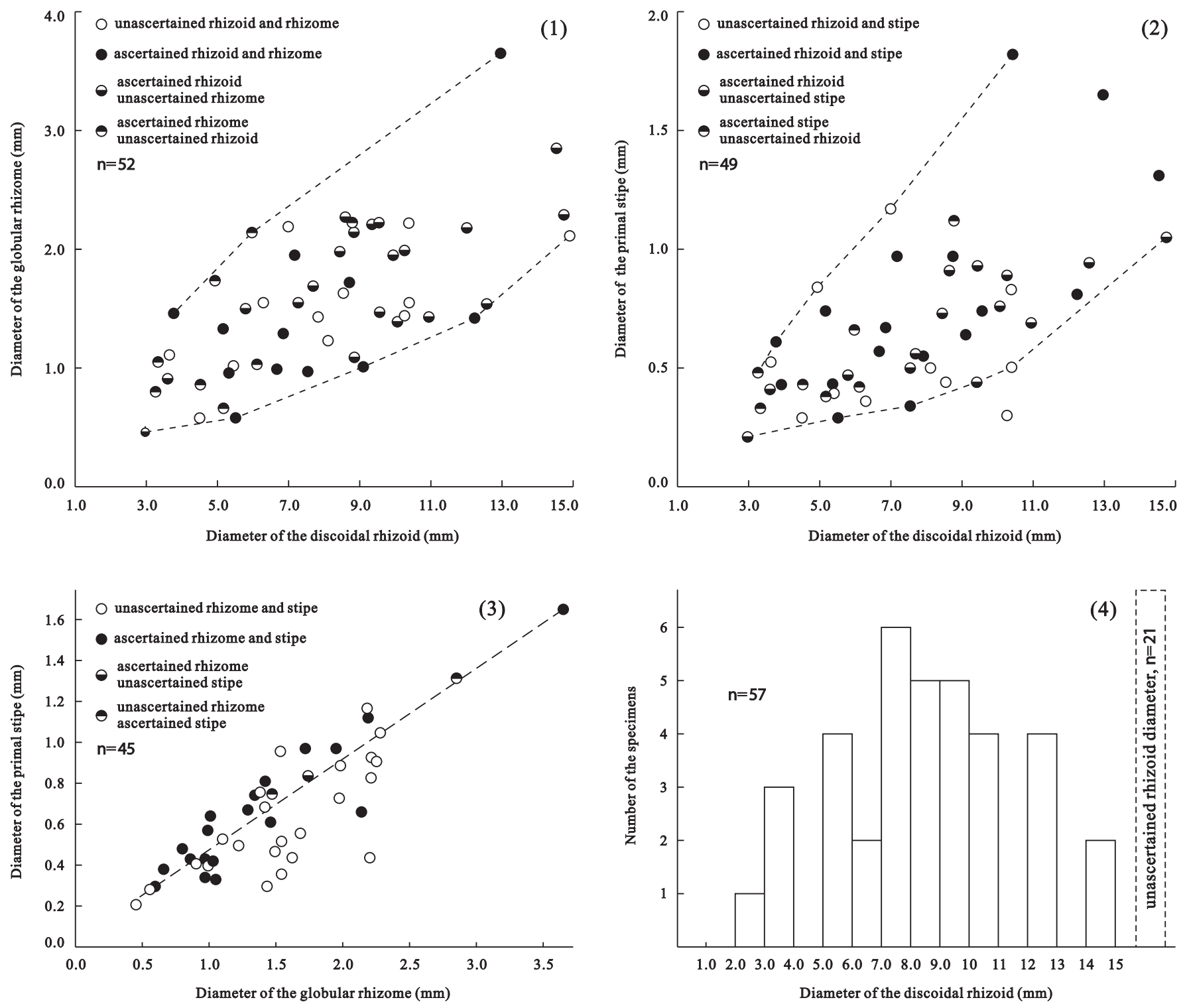

Figure 5. Cross-plots of the diameters of the discoidal rhizoid, the globular rhizome, and the primal stipe (1-3): (1) discoidal rhizoid versus globular rhizome; (2) discoidal rhizoid versus primal stipe; (3) globular rhizome versus primal stipe. (4) Bar graph of rhizoid diameter versus number of specimens.

and globular rhizome, width and length of the stipe, and preserved width and length of the lamina, were measured using an electronic vernier micrometer accurate to $0.01 \mathrm{~mm}$. Because of preservation, the measurement values of the rounded hump formed by the globular rhizome and the circular cross section of the stipe on the discoidal rhizoid were considered, in this paper, as proxies for the diameter of the globular rhizome and the primal stipe.

Based on measurements of 57 specimens of $D$. wenghuiensis n. gen. n. sp., the diameters of the discoidal rhizoid, the globular rhizome, and the primal stipe are closely related with each other (Fig. 5); the diameters of the globular rhizome and the primal stipe, however, are not significantly related to the growth rates of the stipe and lamina widths (Fig. 6).

\section{Morphological features and their interpreted functions}

Discusphyton wenghuiensis n. gen. n. sp., which is found in back shales of the Ediacaran Doushantuo Formation, is characterized by a disc-like compression with an unbranching thallus in its center. It is easily understood and regarded as a macroscopic alga in morphology (Wang et al., 2005, 2007, 2009, 2010, 2014, 2015a, 2016a; Wang and Wang, 2006; Tang et al., 2008a, 2009, 2014; Cheng et al., 2013).

The three-dimensionally preserved stipe of $D$. wenghuiensis n. gen. n. sp. (Fig. 3.1-3.5, 3.7-3.10) confirms its originally cylindrical nature. The cylindrical stipe had a relatively stiff property to support the lamina (no completely and threedimensionally preserved specimen), suspending it in the water column for photosynthesis. Connecting the stipe to the discoidal rhizoid, the globular rhizome is three-dimensionally preserved as a carbonated mass that is thicker than the discoidal rhizoid to form a distinct border with the discoidal rhizoid (Fig. 3.1, 3.2, 3.6). Conversely, a polar of the globular rhizome connecting with the stipe has no obvious boundary (Fig. 3.2, 3.6). One possible interpretation is that the globular rhizome and the cylindrical stipe are different from the discoidal rhizoid in 

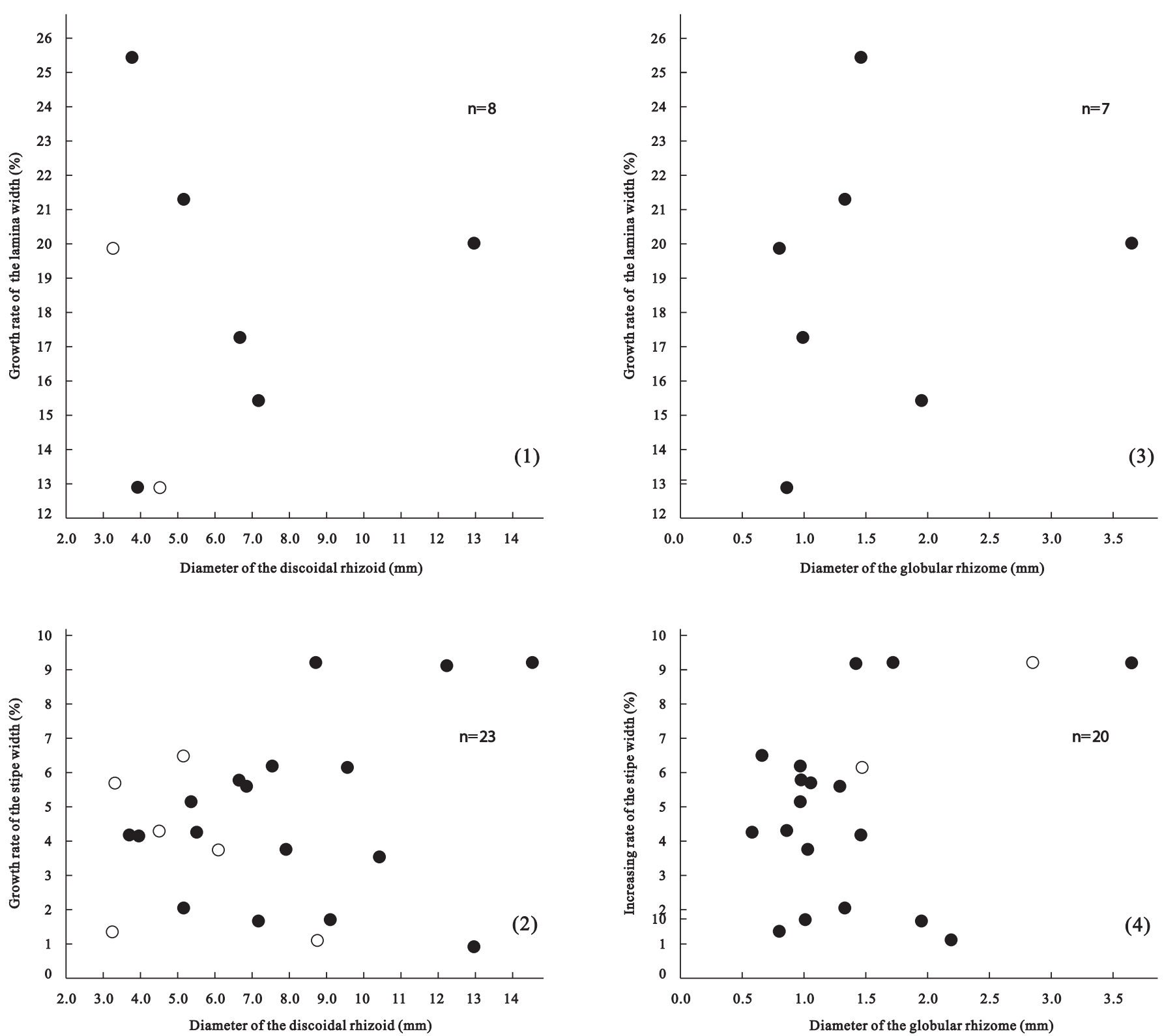

ascertained diameter of the rhizoid or the rhizome

unascertained diameter of the rhizoid or the rhizome

Figure 6. Cross-plots of growth rates of the stipe and the lamina. (1) Rhizoid diameter versus growth rate of the lamina; (2) rhizoid diameter versus growth rate of the stipe; (3) rhizome diameter versus growth rate of the lamina; (4) rhizome diameter versus growth rate of the stipe.

organic matter or tissue density. Moreover, the rounded hump on the surface of the discoidal rhizoid center (Figs. 3.3-3.5, 3.7$3.11,4.2,4.6-4.8)$ implies that the globular rhizome had an originally harder and spherical nature within the discoidal rhizoid. Thus, the spherical rhizome with smooth surface possibly is embedded in the discoidal rhizoid (Fig. 2).

The non-uniform carbonaceous film or mass of the discoidal rhizoid, thinning from the center to the edge (Figs. 3.1$3.3,3.5,3.11,4.1,4.3,4.5-4.9$ ), indicates that the original nature of the discoidal rhizoid is thicker in the center than in the edge. In addition, the semicircularly preserved holdfast is visible as two arc-shaped edges (Fig. 3.7, 3.8), opposite to the thallus, and an obvious rounded hump (Fig. 3.6-3.10), so that it can be interpreted as a folded discoidal rhizoid that was, under certain hydrodynamic conditions, folded towards its bottom. Thus, we believe that $D$. wenghuiensis $\mathrm{n}$. gen. $\mathrm{n}$. sp. has a flat-bottomed and dome-shaped rhizoid, in which a harder and spherical rhizome is embedded (Fig. 2).

In many specimens (Fig. 4.1, 4.2, 4.5-4.9), there is, on the surface of the discoidal rhizoid, a ring-shaped depression surrounding the primal stipe, which can be interpreted either as original in nature or a compression structure. Many researchers considered that the Ediacaran Wenghui biota lived in a relatively low-energy marine environment (e.g., Wang et al., 2005, 2007, 2009, 2011, 2014; Wang and Wang, 2006; Cheng et al., 2013). Using microscopic characteristics of the upper Doushantou back shales and features of macroalgal holdfasts, Wang and Wang (2006) estimated that the upper Duoshantuo back 
shales contained $\sim 78 \%$ water during their deposition. The macroalgal disc-like holdfast was regarded as providing an anchor on the water-rich muddy seafloor (Wang et al., 2005; Wang and Wang, 2006). In the macroagla $D$. wenghuiensis $\mathrm{n}$. gen. n. sp., the spherical rhizome is composed of denser organic matter or tissues than the discoidal rhizoid, and provided an important organ connecting the cylindrical stipe to the domeshaped rhizoid. As the thallus of D. wenghuiensis n. gen. n. sp. swung in the lower-energy seawater, the harder and spherical rhizome, with smooth border, might have rolled to ensure that the dome-shaped rhizoid remained stably anchored on the water-rich muddy seafloor. Thus, the ring-shaped depression on the surface of the discoidal rhizoid is regarded as an organic structure for the swing stipe (Fig. 2), rather than and abiotic structure.

Based on measurement results of D. wenghuiensis $\mathrm{n}$. gen. n. sp., the positive correlations of the diameters of the discoidal rhizoid, the globular rhizome, and the primal stipe show that there is a significant relationship among the three of them (Fig. 5). Apparently, the discoidal rhizoid and the globular rhizome grew up together, during growth of $D$. wenghuiensis $\mathrm{n}$. gen. n. sp., to serve for attaching and stabilizing functions. The primal stipe apparently grew up together with the discoidal rhizoid and the globular rhizome, which may have served for stronger connection to the thallus. However, the growth rates of the stipe width and the lamina width show no apparent relation to the diameters of the globular rhizome and the primal stipe (Fig. 6), implying that the growth of the thallus may have been more easily influenced by photosynthesis.

\section{Problematic affinity of Discusphyton}

In the Ediacaran carbonaceous fossils, the ultrastructural and biochemical characters are generally unavailable, so that the classification of such remains is usually based on its morphology to assess the taxonomic diversity and systematic affinities (Xiao et al., 2002). The morphologies of the disc-like compressions in the Wenghui biota have been considerably modified by taphonomic processes. Moreover, its anatomical details are lacking owing to the homogenized carbonaceous compressions. Therefore, taxonomic assignment of the macroscopic compression is generally based on their characters in populations.

Taxonomic assignment.-Generally, tissue differentiation for serving various bio-functions is considered as a key trait of eukaryotic alga or metaphytes (e.g., Du and Tian, 1985a, b; Zhu and Chen, 1995; Yuan et al., 1995, 2002, 2011; Ding et al., 1996; Chen et al., 2000; Xiao et al., 2002; Wang and Wang, 2006; Wang et al., 2015b). Discusphyton wenghuiensis n. gen. n. sp. in the Ediacaran Wenghui biota is a centimeter-scale macroscopic fossil that had differentiated into the stipe and the lamina main for photosynthesis, the discoidal rhizoid for attaching on the seafloor, and the globular rhizome for connecting the stipe to the rhizoid. The large-sized discoidal rhizoid and the three-dimensionally preserved globular rhizome and stipe indicate that $D$. wenghuiensis $\mathrm{n}$. gen. n. sp. had a holdfast organ to stably attach its body on seafloor and a stronger thallus to enhance its competitiveness for sunlight. Nevertheless, it is a pity that the homogenized carbonaceous compressions lacked microstructural details, so that the phylogenetic affinity of the macroscopic metaphyte $D$. wenghuiensis $\mathrm{n}$. gen. $\mathrm{n}$. sp. cannot be resolved in this paper.

Temporal distribution of disc-like holdfast features.-Holdfast forms in previous publications have been reported in the Precambrian, mainly for indicating the fixation effect and/or tissue differentiation, but little significant attention has been paid to more detailed description and discussion.

The ribbon-like, coiled Grypania Walter, Oehler, and Oehler, 1976, emend. Walter et al., 1990 was commonly regarded as an eukaryotic macroalga (e.g., Walter et al., 1976, 1990; Runnegar, 1991; Hofmann, 1992; Han and Runnegar, 1992; Kumar, 2001; Knoll et al., 2006; Sharma and Shukla, 2009; Xiao, 2013; Wang et al., 2016b). The earliest known occurrence of Grypania was reported from the Palaeoproterozoic Negaumee Iron Formation in Michigan, USA (Han and Runnegar, 1992), dated to $1870 \mathrm{Ma}$ (re-dated by Schneider et al., 2002). Walter et al. (1990) considered that the unbranching $G$. spiralis with a cylindrical body was fixed to the sediment-water interface by an unknown attachment. A rounded terminus at the innermost end of the coiled G. spiralis was interpreted as an expression of the end of its body anchored or nestled into sediments (Wang et al., 2016b). We can understand $G$. spiralis as a benthic macroalga that used its end to serve the fixing function (Fig. 7.1). With holdfasts that were briefly described by Yan and Liu (1997) as the acuminate base (Fig. 7.2) and by Zhu and Chen (1995) as the rhizoidal holdfast (=rhizoid) (Fig. 7.3) and doubtful disc-like holdfast (=?rhizome) (Fig. 7.4), some macroscopic algae were reported in the late Palaeoproterozoic Tuanshanzi Formation (1700 Ma) in North China. In the early Mesoproterozoic Gaoyuzhuang Formation (1560 Ma) in North China, a rod-like holdfast (=rhizome) (Fig. 7.5) and a possible spheroidal holdfast (=?rhizome) (Fig. 7.6) were reported by Zhu et al. (2016), but no detailed description of the two specimens was provided. Previously studied macroalgae from the Mesoproterozoic Vindhyan Supergroup (1000 Ma), Central India, by Kumar (2001) considered that a millimeter-scale alga constituted three parts: the holdfast preserved as Tilsoia (Kumar, 2001) and Suketea (Kumar, 2001), the thallus preserved as Tawuia (Hofmann and Aitken, 1979), and Chuaria (Walcott, 1899), which represented a compressed cyst-like body; that is, the millimeter-scale alga has a holdfast consisting of a discoidal rhizoid (Tilsoia and Suketea) and a rhizoid (the substrate of Tawuia) (Fig. 7.7). Another macroalga, Longfengshania (Du, 1982) (Fig. 7.8), which was first reported in the middle Neoproterozoic Changlongshan Formation (900-860 Myr) in North China ( $\mathrm{Du}, 1982)$, was regarded to have various (tuberous, rhizoidal, and disc-like rhizoid) holdfast forms (Du and Tian, 1985a, b; Liu and Du, 1991) that, however, were not seen in systematic descriptions.

In the early Ediacaran, specimens of branched thallus were reported in the Lantian flora in South China, and the macroalgal holdfasts were also described as globular or tuberous holdfasts (=rhizome) (Fig. 7.9) and disc-like holdfasts (=?rhizome) (Fig. 7.10) (e.g., Chen et al., 1994b; Yuan et al., 1995, 1999, 2002, 2011; Tang et al., 1997, 2009). Abundant and diverse macroscopic algae were reported in the upper Doushantuo black 


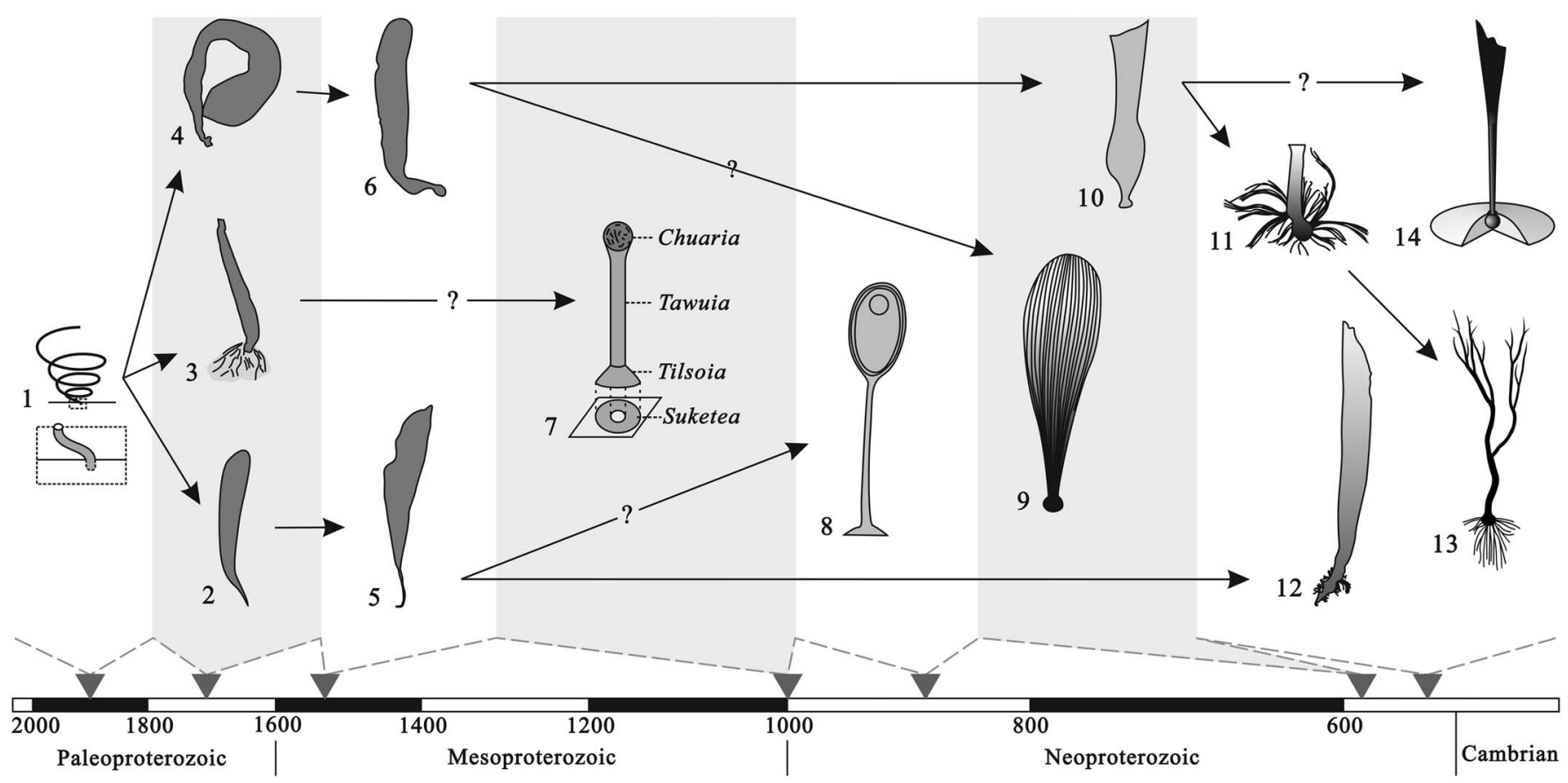

Figure 7. Various forms and possible evolution of the Precambrian macroalgal holdfasts. (1) End part nested into sediments (=?original rhizome) of Grypania, modified from Wang et al. (2016, fig. 3); (2) acuminate base (=?rhizome) of Tuanshanzia, after Yan and Liu (1997, fig. 3); (3) rhizoidal holdfast (=rhizome with filamentous rhizoids) of Zhu and Chen (1995, fig. 3I); (4) doubtful disc-like holdfast (=?rhizome) of Zhu and Chen (1995, fig. 3D); (5) rod-like holdfast (=rhizome) of Zhu et al. (2016, fig. 3d); (6) possible spheroidal holdfast (=?rhizome) of Zhu et al. (2016, fig. 3e); (7) holdfast represented by Tilsoia and Suketea, after Kumar (2001, fig. 16); (8) holdfast of Longfengshania, after Du (1985a, fig. 2); (9) globular or tuberous holdfast (=rhizome) of Flabellophyton, after Yuan et al. (1999, fig. 2F); (10) disc-like holdfast (=?rhizome) of Baculiphyca sp., after Yuan et al. (1999, fig. 2B); (11) globular rhizome with filamentous rhizoids of B. taeniata, after Xiao et al. (2002, fig. 3.2); (12) cuneate rhizome with filamentous rhizoids of Gesinella, after Steiner et al. (1992, pl. 1, fig. 8); (13) tuberous rhizome with filamentous rhizoids of Zhongbaodaophyton, after Wang et al. (2015b, fig. 2); (14) globular rhizome and discoidal rhizoid of Discusphyton new genus. Arrows mark the possible evolutionary trend of the Precambrian macroalgal holdfasts.

shales of the mid-late Ediacaran in South China, and most of their holdfasts commonly consist of a more or less expanded thallus substrate (including globular, tuberous, and cuneate rhizomes) and/or many filamentous rhizoids growing on the expanded rhizome (Fig. 7.11, 7.12) (e.g., Chen and Xiao, 1991, 1992; Chen et al., 1994b, 2000; Ding et al., 1996; Hu, 1997; Xiao et al., 2002; Wang and Wang, 2006; Wang et al., 2007, 2009, 2011, 2014, 2015a, 2016a; Tang et al., 2008a, 2014). Remarkably, there is a rarely known disc-like holdfast of Discusphyton wenghuiensis n. gen. n. sp., consisting of a globular rhizome and a large-sized discoidal rhizoid, but no filamentous rhizoid (Figs. 2, 7.16).

For these fossil records, we consider that the rhizome may have originated as the thallus substrate nestled into sediments and the rhizoid may be the secondary growth of the rhizome. From the brief and/or incomplete descriptions in previous publications, we infer that the variation tendency of the macroalgal holdfast may be from small to large size in its own share of the thalli and from simple to complex in form and structure (Fig. 7). However, it is difficult, at present, to decipher if the discoidal rhizoid originated from the bonded filamentous rhizoid, or an individual of the secondary rhizome, or others.

\section{Conclusions}

With a large-sized disc-like holdfast and an unbranching thallus, Discusphyton whenghuiensis n. gen. n. sp. was collected in the upper Doushantuo black shales ( 560-551 Ma) of the Ediacaran in northeastern Guizhou, South China. The benthic macroalga lived in a relatively low-energy marine environment; it not only had an unbranching thallus, but also recorded the appearance of a complex holdfast. The unbranching thallus, consisting of a compressed lamina (upper part of thallus) and cylindrical stipe (lower part of thallus), mainly served for photosynthesis. The disc-like holdfast is composed of a discoidal rhizoid and a globular rhizome. The discoidal rhizoid is regarded as an originally flat-bottomed and dome-shaped organ that served to anchor its macroalgal body on the water-rich muddy seafloor. Connecting the cylindrical stipe to the dome-shaped rhizoid, the globular rhizome was an originally harder and spherical feature that is composed of denser tissues than the dome-shaped rhizoid. The harder and spherical rhizome with smooth surface is embedded in the dome-shaped rhizoid and may have been an important organ as a steering knuckle to ensure the domeshaped rhizoid stably anchored on the seafloor. However, it is difficult, at present, to decipher the phylogenetic affinity of the macroscopic metaphyte $D$. wenghuiensis $\mathrm{n}$. gen. $\mathrm{n}$. sp. and the origin of discoidal rhizoids.

\section{Acknowledgments}

We thank villagers of Wenghui, Jiangkou, Guizhou, for assistance in the field. This study was supported by the National Science Foundation of China (grant No. 41762001, No. 41663005, and No. 41572024) and CAGS Research Fund of China (grant YYWF201602). 


\section{References}

Chen, M., and Xiao, Z., 1991, Discovery of the macrofossils in the upper Sinian Doushantuo Formation at Miaohe, eastern Yangtze Gorges: Scientia Geologica Sinica, v. 4, p. 317-324.

Chen, M, and Xiao, Z., 1992, Macrofossil biota from upper Sinian Doushantuo Formation in eastern Yangtze Gorges, China: Acta Palaeontologica Sinica, v. 31, p. 513-529.

Chen, M., Xiao, Z., and Yuan, X., 1994a, A new assemblage of megafossilsMiaohe Biota from upper Sinian Doushantuo Formation, Yangtze gorges: Acta Palaeontologica Sinica, v. 33, p. 392-403.

Chen, M., Lu, G., and Xiao, Z., 1994b, Preliminary study on the algal macrofossils: Lantian flora from Lantian Formation of Upper Sinian in Southern Anhui Province: Chinese Academy of Science, Institute of Geology, Collection, v. 7, p. 252-267.

Chen, M., Chen, Q., and Xiao, Z., 2000, Preliminary discussion on the early evolutionary history of macroscopic plants: Scientia Geologica Sinica, v. 35 , p. $1-15$.

Chen, X., and Wang, X., 2002, Morphology and systematic of fossils in the Sinian Wulingshan biota from western Hunan Province: Geological Bulletin of China, v. 21, p. 638-645.

Cheng, L., Wang, Y., Chen, H., Wang, Y., and Zhong, Y., 2013, Sedimentary and burial environment of black shales of Sinian to Early Palaeozoic in Upper Yangtze region: Acta Petrologica Sinica, v. 29, p. 2906-2912.

Condon, D., Zhu, M., Bowring, S., Wang, W., Yang, A., and Jin, Y., 2005, $\mathrm{U}-\mathrm{Pb}$ ages from the Neoproterozoic Toushantuo Formation, China: Science, v. 308, p. 95-98.

De, C., 2003, Possible organisms similar to Ediacaran forms from the Bhander Group, Vindhyan Suppergroup, Late Neoproterozoic of India: Journal of Asian Earth Sciences, v. 2, p. 387-395.

Ding, L., Li, Y., Hu, X., Xiao, Y., Su, C., and Huang, J., 1996, Sinian Miaohe Biota: Beijing, Geological Publishing House, 221 p.

Du, R., 1982, The discovery of the fossils such as Chuaria in the Qingkaikou system in northwestern Hebei and their significance: Geological Review, v. 55 , p. $620-626$.

Du, R., and Tian, L., 1985a, Discovery and preliminary study of mega-alga Longfengshania from the Qingbaikou Syetem of the Yanshan Mountain Area: Acta Geologica Sinica, v. 58, n. 3, p. 19-190.

Du, R., and Tian, L., 1985b, Algal macrofossils from the Qingbaikou System in the Yanshan Range of North China: Precambrian Research, v. 29, p. 5-14.

Duan, J.Y., and Lin, W.X., 1980, The features of the late Pre-Cambrian fauna in south Liaoning and its age range: Journal of Jilin University (Earth Science Edition), v. 2, p. 20-28.

Farmer, J., Vidal, G., Moczydlowska, M., Strauss, H., Ahlberg, P., and Siedlecka, A., 1992, Ediacaran fossils from the Innerelv Member (late Proterozoic) of the Tanafjorden area, northeastern Finnmark: Geological Magazine, v. 129, p. 181-195.

Fedonkin, M.A., 1982, A new generic name for some Precambrian Coelenterates: Paleontologicheskii Zhurnal, v. 2, p. 137-147.

Glaessner, M.F., 1984, The Dawn of Animal Life: Cambridge, Cambridge University Press, $244 \mathrm{p}$.

Han, T.-M., and Runnegar, B., 1992, Megascopic eukaryotic algae from the 2.1-billion-year-old Negaunee Iron-Formation, Michigan: Science, v. 257 p. $232-235$.

Hofmann, H.J., 1992, Proterozoic carbonaceous films, in Schope, J.W., and Klein, C., The Proterozoic Biosphere: A Multidisciplinary Study: Cambridge, Cambridge University Press, p. 349-357.

Hofmann, H.J., and Aitken, J.D., 1979, Precambrian biota from the Little Dal Group, Mackenzie Mountains, northwestern Canada: Canadian Journal of Earth Sciences, v. 16, p. 150-166.

Hu, X., 1997, A study on macrofossils ecostratigraphy in Doushantuo Formation at the Late Sinian in the eastern Yangtze Gorges: Journal of Xi'an College of Geology, v. 19, n. 3, p. 9-13.

Jiang, G., Shi, X., Zhang, S., Wang, Y., and Xiao, S., 2011, Stratigraphy and paleogeography of the Ediacaran Doushantuo Formation (ca. 635-551 Ma) in South China: Gondwana Research, v. 19, p. 831-849.

Keller, B.M., Menner, V.V., Stepanov, V.A., and Chumakov, N.M., 1974 New finds of fossils in the Precambrian Valday Series along the Syuzma River: Izvestia Akademii Nauk SSSR, Seriya Geologicheskaya, v. 12 , p. $130-134$.

Kendall, B., Komiya, T., Lyons, T.W., Bates, S.M., Gordon, G.W., Romaniello, S.J., Jiang, G., Creaser, R.A., Xiao, S., McFadden, K., Sawaki, Y., Tahata, M., Shu, D., Han, J., Li, Y., Chu, X., and Anbar, A.D., 2015, Uranium and molybdenum isotope evidence for an episode of widespread ocean oxygenation during the late Ediacaran Period: Geochimica et Cosmochimica Acta, v. 156, p. 173-193.

Knoll, A.H., Javaux, E.J., Hewitt, D., and Cohen, P., 2006, Eukaryotic organisms in Proterozoic oceans: Philosophical Transactions of the Royal Society, B, v. 361, p. 1023-1038.
Kumar, S., 2001, Mesoproterozoic megafossil Chuaria-Tawuia association may represent parts of a multicellular plant, Vindhyan Supergroup, Central India: Precambrian Research, v. 106, p. 187-211.

Liu, B., and Xu, X., 1994, Atlas of the Lithofacies and Palaeogeography of South China (Sinian-Triassic): Beijing, Science Press, p. 28-33.

Liu, Z., and Du, R., 1991, Morphology and systematics of Longfengshania: Acta Palaeontologic Sinica, v. 30, p. 106-114.

McCall, G.J.H., 2006, The Vendian (Ediacaran) in the geological record: enigmas in geology's prelude to the Cambrian explosion: Earth-Science Reviews, v. 77, p. 1-229.

Qin, S., Zhu, S., Xie, Z., Chen, Y., and Wang, Y., 1984, The upper Precambrian in Guizhou, in Wang, Y., Yin, G., Zheng, S., Qin, S., Zhu, S., Chen, Y., Luo, Q., Zhu, S., Wang, F., and Qian, Y., The Upper Precambrian and Sinian-Cambrian Boundary in Guizhou: Guiyang, The People's Publishing House of Guizhou, p. 37-76.

Runnegar, B., 1991, Precambrian oxygen levels estimated from the biochemistry and physiology of early eukaryotes: Palaeogeography, Palaeoclimatology, Palaeoecology, v. 97, p. 97-111.

Seilacher, A., 1992, Vendobontia and Psammocorallia: lost constructions of Precambrian evolution: Journal of the Geological Society, v. 149, p. 607-613.

Seilacher, A., 1999, Biomat-related lifestyles in the Precambrian: Palaios, v. 14, p. 86-93.

Serezhnikova, E.A., 2007, Vendian Hiemalora from Arctic Siberia reinterpreted as holdfasts of benthic organisms: Geololgical Society, London, Special Publications, v. 286, p. 331-337.

Schneider, D.A., Bickford, M.E., Cannon, W.F., Schulz, K.J., and Hamilton, M.A. 2002, Age of volcanic rocks and syndepositional Iron Formations, Marquette Range Supergroup; implications for the tectonic setting of Paleoproterozoic Iron Formations of the Lake Superior region: Canadian Journal of Earth Sciences, v. 39, p. 999-1012.

Sharma, M., and Shukla, Y., 2009, The evolution and distribution of life in the Precambrian eon-Global perspective and the Indian record: Journal of Biosciences, v. 34, p. 765-776.

Singh, V., K., Babu, R., and Shukla, M., 2009, Discovery of carbonaceous remains from the Neoproterozoic shales of Vindhyan Supergroup, India: Journal of Evolutionary Biology Research, v. 1, p. 1-17.

Sprigg, R.C., 1947, Early Cambrian(?) "jellyfishes" from the Flinders Ranges, South Australia: Royal Society of South Australia Transaction, v. 71, p. 212-224.

Steiner, M., 1994, Die neoproterozoishen Megaalgen Südchinas: Berliner Geowissrnschaftliche Abhandlungen (E), v. 15, p. 1-146.

Steiner, M., Erdtmann, B.D., and Chen, J., 1992, Preliminary assessement of new Late Sinian (Late Proterozoic) large siphonous and filamentous "megaalgae" from eastern Wulingshan, North-Central Hunan, China: Berlinger Geowissenschaftliche Abhandlungen (E), v. 3, p. 305-319.

Sun, W.G., 1986, Precambrian medusoids: the Cyclomedusa piexus and Cyclomedusa-like pseudofossils: Precambrian Research, v. 31, p. 325-360.

Tang, F., Yin, C., and Gao, L., 1997, A new data of metaphyte fossils from the Late Sinian Doushantuo stage at Xiuning, Anhui Province: Acta Geologica Sinica, v. 71, p. 289-296.

Tang, F., Yin, C., Liu, P., Duan, D., and Qao, L., 2008a, Morphological comparison of the Ediacaran Miaohe biota from South China: implications for their affinities and ecology: Acta Geologica Sinica, v. 82, p. 601-611.

Tang, F., Yin, C., Stefan, B., Liu, P., Wang, Z., and Gao, L., 2008b, Octoradiate spiral organisms in the Ediacaran of South China: Acta Geologica Sinica (English Edition), v. 82, p. 27-34.

Tang, F., Yin, C., Liu, P., Gao, L., and Wang, Z., 2009, Neoproterozoic macrofossil records in South China and biostratigraphic successions and correlations: Acta Geoscientica Sinica, v. 30, p. 505-522.

Tang, F., Jin, X., Wang, Y., Ding, M., Zhao, Y., and Gao, L., 2014, Is the Ediacaran Hiemalorathe attachment disc of the Doushantuo macrofossil alga Gesinella? Geological Review, v. 60, p. 1009-1028.

Wade, M., 1972, Hydrozoa and Scyphozoa and other medusoids from the Late Precambrian Ediacaran fauna, South Australia: Palaeontology, v. 15, p. 197-225.

Walcott, C.D., 1899, Precambrian fossiliferous formations: Geological Survey of America Bulletin, v. 10, p. 199-244.

Walter, M.R., Oehler, J.H., and Oehler, D.Z., 1976, Megascopic algae 1300 million years old from the Belt Supergroup, Montana: a reinterpretation of Walcott's Helminthidichnites: Journal of Paleontology, v. 50, p. 872-881.

Walter, M.R., Du, R., and Horodyski, R.J., 1990, Coiled carbonaceous megafossils from the middle Proterozoic of Jixian (Tianjin) and Montana: American Journal of Science, v. 290-A, p. 133-148.

Wang, Y., and Wang, X., 2006, The holdfasts of macroalgae in the Neoproterozoic Doushantuo Formation in northeastern Guizhou Province and their environmental significance: Acta Micropalaeontologica Sinica, v. 23, p. $145-164$

Wang, Y., and Wang, X., 2008, Annelid from the Neoproterozoic Doushantuo Formation in the Northeast Guizhou, China: Acta Geologica Sinica (English Edition), v. 82, p. 257-265. 
Wang, Y., and Wang, X., 2011, New observations on Cucullus Steiner from the Neoproterozoic Doushantuo Formation of Guizhou, South China: Lethaia, v. 44 , p. $275-286$.

Wang, Y., Qin, S., Zhu, S., and Chen, Y., 1987, Proterozoic Eonothem, in Xie, J., Wang, K., and Han, B., eds., Regional Geology of Guizhou Province: Beijing, Geological Publishing House, p. 26-48.

Wang, Y., He, M., Yu, M., Zhao, Y., Peng, J., Yang, Y., and Zhang, Z., 2005, Preliminary discussion on ecological characteristics and buried environments of Miaohe-type biota during the Late Doushantuoian of Sinian in northeastern Guizhou Province: Journal of Palaeogeography, v. 7, p. 328-335.

Wang, Y., Wang, X., and Huang, Y., 2007, Macroscopic algae from the Ediacaran Doushantuo Formation in Northeastern Guizhou, South China: Earth Science, v. 32, p. 828-844.

Wang, Y., Wang, X., and Huang, Y., 2008, Megascopic symmetrical metazoans from the Ediacaran Doushantuo Formation in northeastern Guizhou, South China: Journal of China University of Geosciences, v. 19, p. 200-206.

Wang, Y., Zhao, M., Yang, Y., and Wang, X., 2009, Emergence of marcoorganismal ecosystem of the Late Doushantuoian of the Ediacaran in South China, and its significances: Journal of Palaeogeography, v. 6, p. 640-650.

Wang, Y., Lei, L., Chen, H., and Hou, M., 2010, Development of the Ediacaran (Sinian) multicellular organisms and formation of the source rocks in the Yangtze area: Sedimentary Geology and Tethyan Geology, v. 30, p. 30-38.

Wang, Y., Chen, H., Wang, X., and Huang, Y., 2011, Research on succession of the Ediacaran Doushantuoian meta-community in Northeast Guizhou, South China: Acta Geologica Sinica (English Edition), v. 85, p. 533-543.

Wang, Y., Huang, Z., Chen, H., Hou, M., Yang, Y., and Du, B., 2012, Stratigraphical correlation of the Liuchapo Formation with the Dengying Formation in South China: Journal of Jilin University (Earth Science Edition), v. 42 , p. $328-335$

Wang, Y., Wang, Y., Du, W., and Wang, X., 2014, The correlation between macroscopic algae and metazoans in the Ediacaran: a case study on the Wenghui biota in northeastern Guizhou, South China: Australian Journal of Earth Sciences, v. 61, p. 967-977.

Wang, Y., Du, W., Komiya, T., Wang, X., and Wang, Y., 2015a, Macroorganism paleoecosystems during the middle-late Ediacaran Period in the Yangtze Block, South China: Paleontological Research, v. 19, p. 237-250.

Wang, Y., Wang, Y., Du, W., and Wang, X., 2015b, The Ediacaran macroalga Zhongbaodaophyton Chen et al. from South China: Alcheringa, v. 39, p. 377-387.

Wang, Y., Wang, Y., Du, W., and Wang, X., 2016a, New data of macrofossils in the Ediacaran Wenghui biota from Guizhou, South China: Acta Geologica Sinica (English Edition), v. 90, 1611-1628.

Wang, Y., Wang, Y., and Du, W., 2016b, The long-ranging macroalga Grypania spiralis from the Ediacaran Doushantuo Formation, Guizhou, South China: Alcheringa, v. 40, 303-312.

Xiao, S., 2013, Written in stone: the fossil record of early eukaryotes, in Trueba, G., and Montufar, C., Evolution from the Galapagos, Social and Ecological Interactions in the Gapalagos Island 2: New York, Springer, p. 107-124.

Xiao, S., Knoll, A.H., and Yuan, X., 1998, Morphological reconstruction of Miaohephyton bifurcatum, a possible brown alga from the Doushantuo
Formation (Neoproterozoic), South China, and its implications for stramenopile evolution: Journal of Paleontology, v. 72, p. 1072-1086.

Xiao, S., Yuan, X., Steiner, M., and Knoll, A.H., 2002, Macroscopic carbonaceous compressions in a terminal Proterozoic shale, a systematic reassessment of the Miaohe biota, South China: Journal of Paleontology, v. 76, p. 347-376.

Xiao, S., Droser, M., Gehling, J.G., Hughes, I.V., Wan, B., Chen, Z., and Yuan, X., 2013, Affirming life aquatic for the Ediacara biota in China and Australia: Geology, v. 41, p. 1095-1098.

Yan, Y., and Liu, Z., 1997, Tuanshanzian macroscopic algae of 1700Ma B.P. from Changcheng System of Jixian, China: Acta Palaeontologica Sinica, v. 36, p. $18-41$

Yuan, X., Li, J., and Chen, M., 1995, Development and their fossil records of metaphytes from Late Precambrian: Acta Palaeontologica Sinica, v. 34, p. 90-102.

Yuan, X., Li, J., and Cao, R., 1999, A diverse metaphyte assemblage from the Neoproterozoic black shales of South China: Lethaia, v. 32, p. 143-155.

Yuan, X., Xiao, S., Yin, L., Knoll, A.H., Zhou, C., and Mu, X., 2002, Doushantuo Fossils, Life on the Eve of Animal Radiation: Hefei, University of Science and Technology of China Press, 171 p. [in Chinese with English summary]

Yuan, X., Chen, Z., Xiao, S., Zhou, C., and Hua, H., 2011, An early Ediacaran assemblage of macroscopic and morphologically differentiated eukaryotes: Nature, v. 470 , p. $390-393$.

Zhang, X., Hua, H., and Reitner, J., 2006, A new type of Precambrian megascopic fossils: the Jinxian biota from northeastern China: Facies, v. 52, p. $169-181$

Zhu, B., Becker, H., Jiang, S., Pi, D., Fischer-Gödde, M., and Yang, J., 2013, Re-Os geochronology of black shales from the Neoproterozoic Doushantuo Formation, Yangtze Platform, South China: Precambrian Research, v. 225, p. 67-76.

Zhu, M., Zhang, J., and Yang, A., 2007, Integrated Ediacaran (Sinian) chronostratigraphy of South China: Palaeogeography, Palaeoclimatology, Palaeoecology, v. 254, p. 7-61.

Zhu, M., Gehling, J.G., Xiao, S., Zhao, Y., and Droser, M.L., 2008, Eight-armed Ediacara fossil preserved in contrasting taphonomic windows from China and Australia: Geology, v. 36, p. 867-870.

Zhu, S., and Chen, H., 1995, Megascopic multicellular organisms from the 1700-million-year-old Tuanshanzi Formation in the Jixian area, North China: Science, v. 270, p. 620-622.

Zhu, S., Zhu, M., Knoll, A.H., Yin, Z., Zhao, F., Sun, S., Qu, Y., Shi, M., and Liu, H., 2016, Decimetre-scale multicellular eukaryotes from the 1.56-billion-year-old Gaoyuzhuang Formation in North China: Nature Communications, v. 7, 11500 doi: $10.1038 /$ ncomms 11500 .

Zhu, W., and Chen, M., 1984, On the discovery of macrofossil algae from the late Sinian in the eastern Yangtze Gorges, South China: Acta Botanica Sinica, v. 26, p. 558-560.

Accepted 25 May 2017 